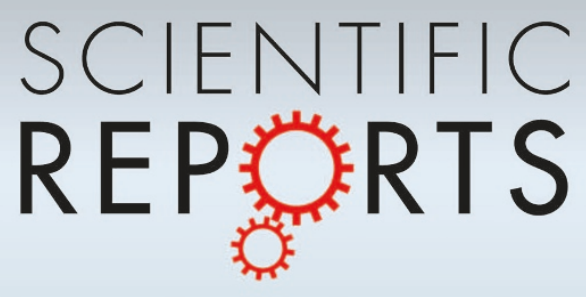

OPEN

SUBJECT AREAS:

COORDINATION

CHEMISTRY

CHEMICAL MODIFICATION

CHEMICAL SYNTHESIS

DRUG DISCOVERY AND

DEVELOPMENT

Received

5 October 2012

Accepted

7 February 2013

Published

19 March 2013

Correspondence and requests for materials should be addressed to P.N.S. (patrycja. nowak-sliwinska@ chuv.ch) or P.J.D. (paul.dyson@epfl.ch)

\section{Synthesis and characterization of a new class of anti-angiogenic agents based on ruthenium clusters}

\author{
Alexey A. Nazarov' ${ }^{1,2}$, Mathurin Baquié', Patrycja Nowak-Sliwinska ${ }^{1,3}$, Olivier Zava', Judy R. van \\ Beijnum ${ }^{4}$, Michael Groessl' ${ }^{1}$, Danielle M. Chisholm ${ }^{5}$, Zohrab Ahmadi ${ }^{5}$, J. Scott Mclndoe ${ }^{5}$, \\ Arjan W. Griffioen ${ }^{4}$, Hubert van den Bergh' \& Paul J. Dyson'
}

${ }^{1}$ Institute of Chemical Sciences and Engineering, Swiss Federal Institute of Technology (EPFL), CH-1015 Lausanne, Switzerland, ${ }^{2}$ Department of Chemistry, Moscow State University, Leninskie Gory, 1 19991, Moscow, Russia, ${ }^{3}$ Urology Department, University Hospital (CHUV) CH-1011, Lausanne, Switzerland, ${ }^{4}$ Angiogenesis Laboratory, Department of Medical Oncology, VU University Medical Center 1081 HV, Amsterdam, The Netherlands, ${ }^{5}$ Department of Chemistry, University of Victoria, P.O. Box 3065, Victoria, British Columbia V8W 3V6, Canada.

New triruthenium-carbonyl clusters derivatized with glucose-modified bicyclophosphite ligands have been synthesized. These compounds were found to have cytostatic and cytotoxic activity and depending on the number of bicyclophosphite ligands, and could be tuned for either anti-cancer or specific anti-angiogenic activity. While some compounds had a broad cellular toxicity profile in several cell types others showed endothelial cell specific dose-dependent anti-proliferative and anti-migratory efficacy. A profound inhibition of angiogenesis was also observed in the in vivo chicken chorioallantoic membrane (CAM) model, and consequently, these new compounds have considerable potential in drug design, e.g. for the treatment of cancer.

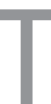

he development of metal-based anti-cancer compounds has traditionally focused on cytotoxic platinumbased compounds, several of which are widely applied in the clinic ${ }^{1-3}$. In recent years, however, there has been increasing interest in the development of ruthenium-based anticancer compounds that appear to operate via very different mechanisms, as compared to the clinically used platinum drugs ${ }^{4-6}$. Indeed, ruthenium complexes tend to be less cytotoxic towards cancer cells in vitro and their propensity to bind DNA is lower. Two ruthenium compounds, indazolium trans-[tetrachlorobis( $1 \mathrm{H}$-indazole)ruthenate(III)]), termed $\mathrm{KP} 1019^{7}$, and imidazolium trans-[tetrachloro(dimethylsulfoxide)(1H-imidazole)ruthenate(III)]), termed NAMI- ${ }^{8}$, are presently in phase II clinical trials, the latter compound showing both anti-metastatic and anti-angiogenic activity in preclinical models. We recently found that a very different type of ruthenium compound, organometallic ruthenium(II) complexes, $\left[\mathrm{Ru}\left(\eta^{6}\right.\right.$-arene) $\left.\mathrm{Cl}_{2}(\mathrm{PTA})\right]$ (arene $=$ toluene and $p$ cymene, PTA $=1,3,5$-triaza-7-phosphaadamantane), also exhibit anti-metastatic ${ }^{9}$ and anti-angiogenic ${ }^{10}$ properties. Indeed, the effect of these small molecules was at least equivalent to that of sunitinib/Sutent ${ }^{\circledR}$ or sorafenib/Naxavara, clinically used tyrosine kinase inhibitors with anti-angiogenic properties ${ }^{11}$. The promising activities of the ruthenium compounds dictate the need for information on their biomolecular targets and suggests a clinical relevance. In this respect a large number of ruthenium compounds have been evaluated in vitro although classical in vitro cytotoxicity screens have proven, in the past, not to be particularly informative of in vivo activity ${ }^{4,12}$.

While most ruthenium-based compounds that have been evaluated as putative anti-cancer agents are mononuclear species with the central ruthenium ion in the $2+$ or $3+$ oxidation states, a few studies describing the in vitro activity of ruthenium $(0)$ and osmium (0) clusters have been published ${ }^{13,14}$. Many of these cluster compounds contain carbon monoxide (CO) and/or other ligands, and notably, the biological importance of $\mathrm{CO}$ as an essential mediator of numerous effects, including anti-inflammatory- and anti-proliferative activity, has recently been reported ${ }^{15}$. Indeed, a number of $\mathrm{CO}$ releasing compounds show promising pharmacological properties ${ }^{16-18}$. Consequently, we decided to determine the anti-angiogenic activity of the family of ruthenium-carbonyl clusters in a series of in vitro assays and based on highly promising results we conducted an in vivo study with these cluster compounds. 


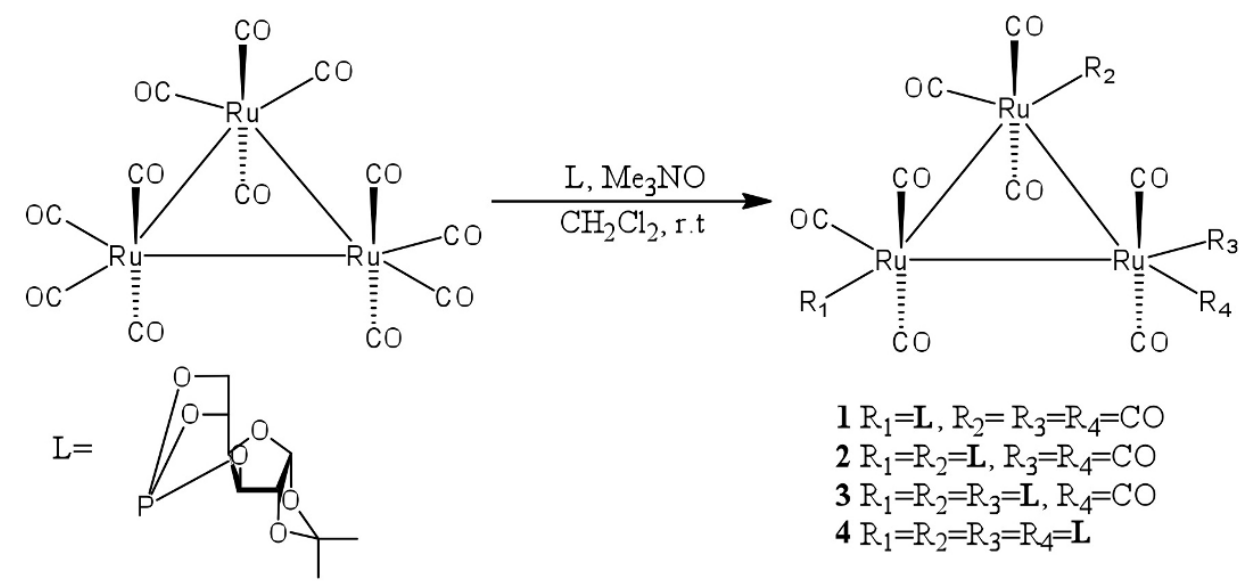

Figure 1 Synthesis of ruthenium-carbonyl clusters with the 3,5,6-bicyclophosphite-1,2-o-isopropylidene- $\alpha$-D -glucofuranoside ligand.

\section{Results}

Triruthenium dodecacarbonyl, $\mathrm{Ru}_{3}(\mathrm{CO})_{12}$, was derivatized with a glucose-modified bicyclophosphite ligand ${ }^{19,20}$ affording four different compounds $(1-4$, Figure 1). The procedure involves treatment of $\mathrm{Ru}_{3}(\mathrm{CO})_{12}$ with trimethylamine- $N$-oxide (that oxidatively removes $\mathrm{CO}$ ligands in a stoichiometric fashion generating a vacant coordination site) in $\mathrm{CH}_{2} \mathrm{Cl}_{2}$ containing the bicyclophosphite ligand. By varying the stoichiometry of the reagents (see Experimental Section for details) substitution of up to four carbonyl ligands by the phosphite can be achieved. Chromatographic separation of the products is required to obtain analytically pure material and 4 is the only obtained as a side-product.

The ${ }^{1} \mathrm{H}$ and ${ }^{13} \mathrm{C}$ signals of the bicyclophosphite ligand(s) in the NMR spectra of $1-4$ change slightly upon coordination to the ruthenium cluster core. More significant changes are observed in the ${ }^{31} \mathrm{P}$ NMR spectra with singlets observed at $\delta 149.9 \mathrm{ppm}$ for 1 and at $\delta 150.3$ for 3 (cf. the free ligand $\delta=119.0$ ). The ${ }^{31} \mathrm{P}$ NMR spectrum of 2 is more complicated due to dynamic behavior and appears as a set of two (broad) singlets at room temperature $(\delta=$ 149.7 and 148.4), which splits to three singlet resonances at $-75^{\circ} \mathrm{C}$ (such behavior has been noted for related complexes) ${ }^{21,22}$. The ${ }^{31} \mathrm{P}$ NMR spectrum of $\mathbf{4}$ is highly complicated as each bicyclophosphite ligand is in a unique environment and they are also undergoing dynamic processes on the NMR timescale.

Electrospray ionization mass spectrometry (ESI-MS) was used to characterize $\mathbf{1}-\mathbf{3}$, and for each cluster a parent ion was observed corresponding the intact compound with an associated sodium cation, i.e. $[\mathrm{M}+\mathrm{Na}]^{+}$. In addition, in order to delineate the relative stability of the ligands, i.e. the carbonyl ligands versus the bicyclophosphite ligands, energy-dependent ESI-MS experiments ${ }^{23}$ were conducted (Figure 2). These revealed that the CO ligands dissociate in preference to the bicyclophosphite ligands in $\mathbf{1}-\mathbf{3}$. Interestingly, the greater the number of bicyclophosphite ligands in the cluster, the greater the proportion of $\mathrm{CO}$ ligands that are lost before ligand decomposition and/or dissociation takes over, despite the fact that these clusters have fewer CO ligands to begin with. Thus, 1 has $11 \mathrm{CO}$ ligands and loses only five COs before dissociation of the bicyclophosphite ligand commences, whereas 3 has nine CO ligands and seven of them are lost before decomposition of the bicyclophosphite ligands begins to compete with $\mathrm{CO}$ loss. The clusters are likely stabilized by the ability of the bicyclophosphite ligands to fold back and bind to the vacant coordination sites as CO ligands are successively removed and, hence, 1 does this least effectively as it has only one bicyclophosphite ligand. At $45 \mathrm{~V}$ and above, bicyclophosphite ligand dissociation (green) and bicyclophosphite ligand decomposition (blue) are observed as competitive processes. The spectrum at the top is a summation of the 150 spectra used to generate the contour map. Disappearance of ion intensity at high collision energy is due to dissociation of $\mathrm{Na}^{+}$(responsible for the charge on the complex).

While extensive $\mathrm{CO}$ ligand loss can be induced in the gas phase in aqueous solution, $\mathbf{1}-\mathbf{3}$ are moderately soluble and stable for days. No signs of hydrolysis or decomposition were observed by ${ }^{31} \mathrm{P}$ NMR spectroscopy. The $\log \mathrm{P}_{\mathrm{o} / \mathrm{w}}$ values of $\mathbf{1}-\mathbf{3}$ were determined (see Table 1).

Compounds $\mathbf{1}$ - $\mathbf{3}$ were initially screened for activity to inhibit cell growth in four human cancer cell lines and an endothelial cell line (Table 1) using a proliferation assay. Clusters $\mathbf{1}$ and $\mathbf{2}$ were similarly active on the different cells, with $\mathrm{IC}_{50}$ values in the range 0.1 $0.8 \mu \mathrm{M}$, after a 72 hour exposure time. In contrast, 3 is not cytotoxic in the four cancer cell lines ( IC $_{50}>300 \mu \mathrm{M}$ ), but shows cytotoxicity towards the ECRF24 endothelial cells (ca. $60 \mu \mathrm{M})$. Intracellular uptake of ruthenium was also determined (Table 1) with uptake of 1 being approximately a thousand times higher than that of 3 , indicating that the differences in $\log \mathrm{P}_{\mathrm{o} / \mathrm{w}}$ values do not entirely account for differences in uptake. Upon treatment with 1 or $2(60 \mu \mathrm{M})$ a significant sub-population of A2780 cells underwent apoptosis. The least cytotoxic compound 3 did not induce apoptosis (Table 2), neither in endothelial, nor cancer cells, but led to cell cycle arrest in the G0/G1 phase.

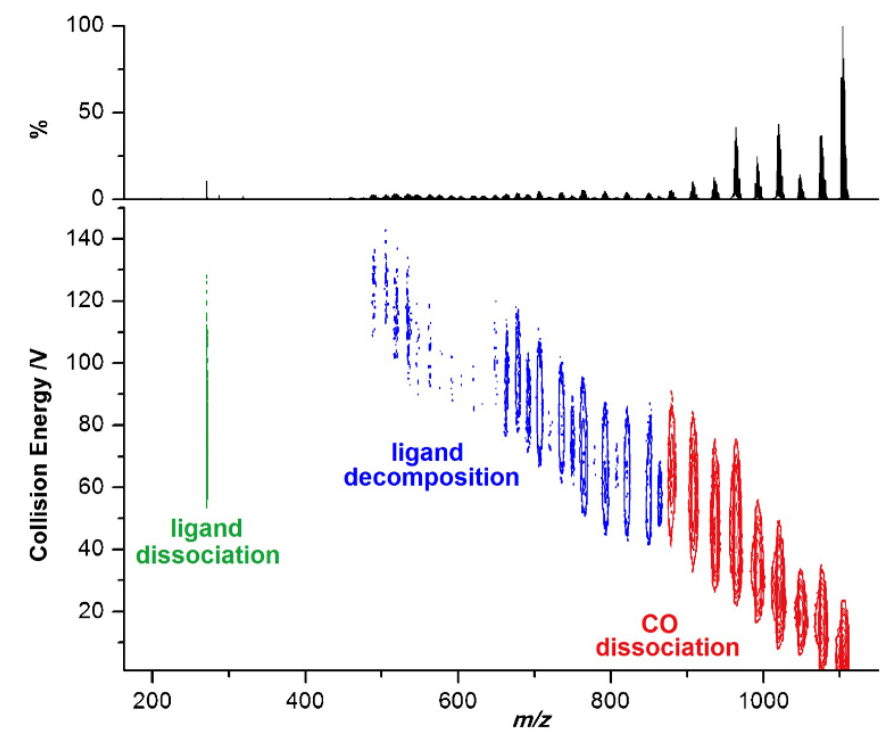

Figure $2 \mid$ Positive-ion energy-dependent ESI-MS of $[2+\mathrm{Na}]^{+}$as a representative example. 
Table 1 | Cytotoxicity towards A2780, A2780cisR, HT29 and A549 cancer cells, and ECRF24 endothelial cells, and intracellular uptake in $\mathrm{A} 2780$ cells and $\log \mathrm{P}_{\mathrm{o}} / \mathrm{w}$ values of $1-3$. Errors represent the standard error of the mean (SEM)

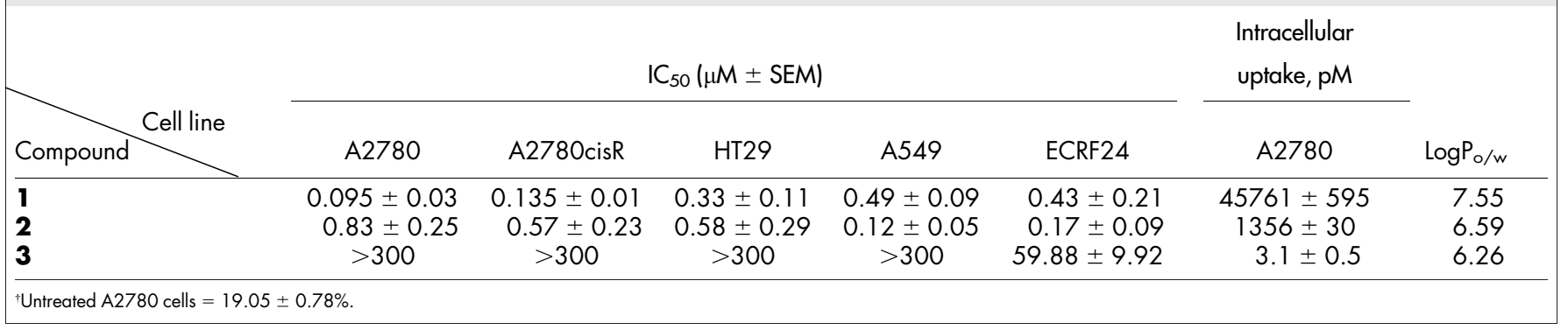

The process of angiogenesis depends, next to proliferation, also on migration of endothelial cells. Therefore the compounds were tested in a cell migration assay. This was performed on cultures of ECRF24 human endothelial cells and invasive MDA-MB-231 human breast adenocarcinoma cells (Figure 3). Cluster 1 did not affect ECRF24 mobility at the tested concentration range $(0.1-62 \mu \mathrm{M})$, but significantly inhibited the mobility of MDA-MB-231 cells, already at $0.1 \mu \mathrm{M}$ (by ca. $60 \%$ ), and by $95 \%$ at $3 \mu \mathrm{M}$ (Figure $3 \mathrm{~A},{ }^{*} \mathrm{P}<0.05$ ). Interestingly, 3 did not affect the mobility of the adenocarcinoma cells, even concentrations of up to $50 \mu \mathrm{M}$ were ineffective, while the ECRF24 cells were more sensitive to this compound. Migration was inhibited by approximately $30 \%$ at $60 \mu \mathrm{M}$ (Figure $3 \mathrm{~B},{ }^{*} \mathrm{P}<0.05$ ). Figure $3 \mathrm{C}$ shows examples of the wound images of confluent ECRF24 layers before $(\mathrm{T}=0 \mathrm{~h})$ and after 7 hours incubation $(\mathrm{T}=7 \mathrm{~h})$ with 3 $(60 \mu \mathrm{M})$.

To check for potential anti-angiogenic activity in vivo, 1 and 3 were tested in the chicken embryo chorioallantoic membrane (CAM) assay. The clusters were topically applied daily for 3 days starting treatment at embryo development day 6 (EDD6), when vascularization of the membrane starts to increase exponentially. The drugs were applied at $150 \mu \mathrm{M}$ concentration as homogeneous solutions in $0.9 \% \mathrm{NaCl}$. Figure $4 \mathrm{~A}$ shows typical fluorescence angiographies taken at EDD9 for the control and treated CAMs. In the control embryos, the capillary plexus was well developed and a homogeneous vascularization was observed (Figure 4A). In contrast, neovascularization was inhibited after treatment with the clusters. A clear and strong effect was observed with 3, indicated in Figure $4 \mathrm{~A}$ as black avascular zones in angiographies (red arrowheads). A lesser effect was seen for 1 . This was quantified by digital assessment of the number of branching points per $\mathrm{mm}^{2}$ and the mean mesh size $\left(10^{2} \mu \mathrm{m}^{2}\right)$, which revealed statistically significant differences $(* \mathrm{P}<$ 0.05). The number of branching points $/ \mathrm{mm}^{2}$ dropped from $2019 \pm$ 45 (control) to $1212 \pm 61$ for 1 and $428 \pm 70$ for 3 (Figure $4 \mathrm{~B}$ ). The mean mesh size increased from $5.4 \pm 0.2$ (control) to $8.9 \pm 0.3$ for 1 and $31.0 \pm 15.0$ for $3\left(10^{2} \mu \mathrm{m}^{2}\right.$, Figure $\left.4 \mathrm{C}\right)$.

Table 2 | Cell-cycle alterations were evaluated using PI-FACS analysis and a representative result is presented in ECRF24 and A2780 cells Apoptosis rates were measured by PI-FACS analysis $(n=4)$ after $72 \mathrm{~h}$ incubation with two concentrations of drugs $1-3$

\section{Compound}

$(\mu M)$

ECRF24

A2780

\begin{tabular}{lrrcrrrr}
\hline & G1/G0 & G2/M & Apoptosis & & G1/G0 & G2/M & Apoptosis \\
\cline { 1 - 4 } $1(0.17)$ & 54.6 & 27.3 & 6.16 & 68.0 & 13.5 & 0.2 \\
$1(0.43)$ & 7.9 & 2.5 & 44.8 & & 50.8 & 28.9 & 8.8 \\
$2(0.06)$ & 15.1 & 4.5 & 45 & & 16.0 & 11.2 & 47.1 \\
$2(0.17)$ & 20.7 & 7.4 & 34.7 & & 22.4 & 19.2 & 26.5 \\
$3(20)$ & 56.2 & 30.8 & 3.2 & 63.3 & 9.2 & 0.5 \\
$3(60)$ & 61.6 & 25.6 & 3.2 & 61.7 & 32.7 & 0.3 \\
\hline
\end{tabular}

\section{Discussion}

In order to obtain physiologically compatible triruthenium cluster compounds, triruthenium dodecacarbonyl, $\mathrm{Ru}_{3}(\mathrm{CO})_{12}$, was derivatized with a glucose-modified bicyclophosphite ligand ${ }^{19,20}$ affording 1 - 4. All four compounds were fully characterized by spectroscopic and analytical methods. It was found that the bicyclophosphite ligand significantly alters the chemical and biological properties of compounds, e.g. influencing solubility, uptake, and biomolecular interactions $\mathrm{s}^{24,25-28}$. Compounds $\mathbf{1}-\mathbf{3}$ are moderately soluble and stable in aqueous solutions for days (no signs of hydrolysis or decomposition were observed). This behavior differs to that of most ruthenium(II) and ruthenium(III) compounds that rapidly undergo hydrolysis. In the gas phase CO loss may be induced from the cluster core with a strong preference for loss of CO relative to the bicyclophosphite ligand(s) as determined by ESI-MS. The overall behavior observed is in stark contrast to the clusters $\mathrm{Ru}_{3}(\mathrm{CO})_{12-n}\left(\mathrm{PPh}_{3}\right)_{n}(n$ $=1-3$ ), where the triphenylphosphine ligands are the first to dissociate from the clusters under energetic fragmentation conditions ${ }^{29}$. The $\log \mathrm{P}_{\mathrm{o} / \mathrm{w}}$ values of $\mathbf{1}-\mathbf{3}$ are as expected, as the number of bicyclophosphite ligands increases the compounds become increasingly hydrophilic, see Table 1.

The number of bicyclophosphite ligands attached to the cluster core significantly influences the biological activity of compounds 1 3. Clusters $\mathbf{1}$ and $\mathbf{2}$ were similarly cytotoxic on the different cancer cell lines $\left(\mathrm{IC}_{50}\right.$ values in the range $0.1-0.8 \mu \mathrm{M}$ ), whereas 3 is not cytotoxic in the four cancer cell lines $\left(\mathrm{IC}_{50}>300 \mu \mathrm{M}\right)$, but is moderately cytotoxic towards the endothelial cells (ca. $60 \mu \mathrm{M})$. These results match closely with the $\log \mathrm{P}_{\mathrm{o} / \mathrm{w}}$ values (Table 1 ); the most lipophilic compound, 1 , is also the most cytotoxic, and 3 , which is the least cytotoxic compound, is also the least lipophilic. Intracellular uptake of ruthenium was also determined (Table 1) with uptake of 1 being approximately a thousand times higher than that of 3 . The differences in $\log \mathrm{P}_{\mathrm{o} / \mathrm{w}}$ values do not entirely account for differences in uptake. It is suggested that the mechanism of anti-proliferative activity of the compounds is only partly based on apoptosis induction (Table 2). Compound 1 at high concentrations showed more pronounced apoptosis in endothelial cells (ECRF24) compared to cancer cells (A2780). Compound 2, which showed a modest anti-angiogenic effect, shows essentially equivalent apoptosis in both cell lines. Compound 3 , showing a clear anti-angiogenic activity in vivo, arrests the cell cycle in the G1/G0 phase leading to senescence, and not leading to direct apoptosis.

The compounds were tested in a cell migration assay on ECRF24 human endothelial cells and invasive MDA-MB-231 human breast adenocarcinoma cells. The resulting data show that two hallmarks of angiogenesis, namely endothelial cell proliferation and, to the lesser extent, migration are inhibited by 3 , while these effects were absent in tumor cells. Consequently the anti-angiogenic activity of $\mathbf{1}$ and $\mathbf{3}$ was tested in vivo in the chicken embryo chorioallantoic membrane (CAM) assay. Under the applied conditions neovascularization was inhibited after treatment with the clusters with a clear and strong effect observed with 3 (Figure 4A) and a lesser effect was seen for 1 . 


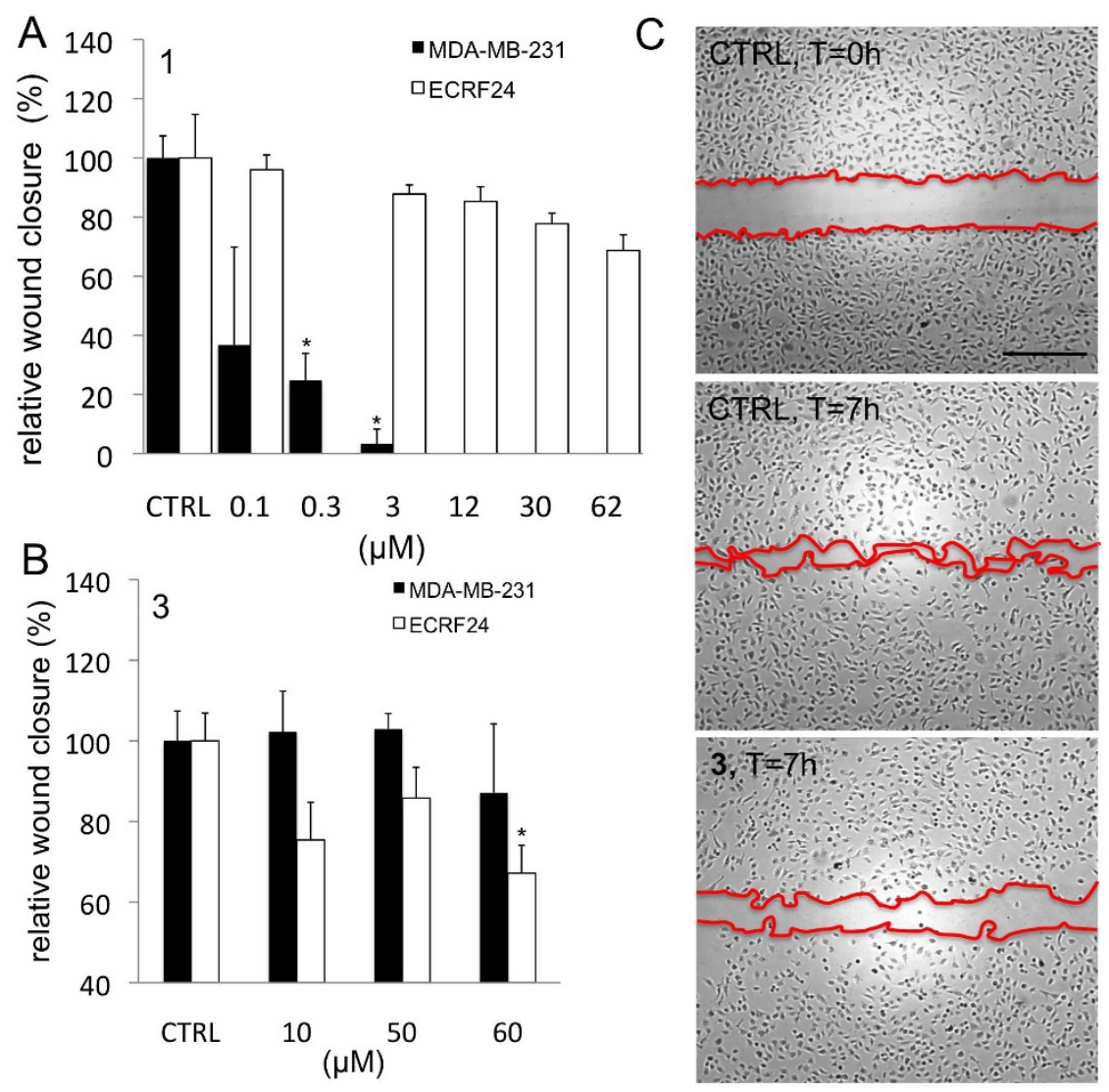

Figure 3 Migration inhibition assessment of ECRF24 and MDA-MB-231 cells after exposure to compound 1 and 3 . Wound closure in ECRF24 cultures after $7 \mathrm{~h}$ of incubation with concentration ranges of $\mathbf{1}(\mathbf{A})$ and $\mathbf{3}(\mathbf{B})$. (C) Typical images of the wound at the beginning of the experiment (culture medium as a control) and after $7 \mathrm{~h}$ of incubation with 3, $60 \mu \mathrm{M}$. Error bars represent standard error of the mean. $* \mathrm{P}<0.05$.

The results show a clear inhibition of angiogenesis, especially for 3 , which matched the effects observed in endothelial proliferation and migration assays. Interestingly, the anti-angiogenic activity of 3 clearly outperformed the FDA-approved small-molecule angiogenesis inhibitors sorafenib (Bayer and Onyx Pharmaceuticals) ${ }^{30,11}$ and sunitinib (Pfizer) ${ }^{31}$. These approved drugs exert angiogenic inhibition via multiple targets including Raf serine/threonine kinases, vascular endothelial growth factor receptor tyrosine kinases: VEGFR-1/ VEGFR-2/VEGFR-3/platelet-derived growth factor receptor $\beta$, PDGFR- $\beta$ (sorafenib); or VEGFRs/PDGFR- $\beta /$ c-KIT/FLT-3 (sunitinib $)^{32}$. For comparison, at $150 \mu \mathrm{M}$, the number of branching point/ $\mathrm{mm}^{2}$ values are approximately 1100 for sorafenib and 1450 for sunitinib, compared to 428 for 3.

To conclude, a highly selective anti-angiogenic triruthenium cluster, $\mathbf{3}$, is reported. Since clusters represent molecular species intermediate between single metal complexes and metal nanoparticles they occupy a unique position for medicinal applications. Compared to mononuclear complexes, far more diversity can be added to a cluster framework. In comparison to nanoparticles, rational synthetic methods can be used to produce precisely designed molecular structures. Indeed, it was shown that slight changes to the peripheral ligands completely switched the biological activity of the cluster. Although the target (or targets) of these clusters remains to be delineated, the in vivo results demonstrate that 3 exhibits an intrinsic angiostatic activity of high clinical relevance.

\section{Methods}

Compound characterization. ${ }^{1} \mathrm{H}(400.13 \mathrm{MHz}),{ }^{31} \mathrm{P}\left\{{ }^{1} \mathrm{H}\right\}(161.98 \mathrm{MHz})$ and ${ }^{13} \mathrm{C}\left\{{ }^{1} \mathrm{H}\right\}$ $(100.62 \mathrm{MHz}) \mathrm{NMR}$ spectra were recorded at $25^{\circ} \mathrm{C}$ on a Bruker Avance II 400 Spectrometer and referenced to residual solvent peaks $\left(\mathrm{CDCl}_{3}{ }^{1} \mathrm{H} 7.26,{ }^{13} \mathrm{C}\left\{{ }^{1} \mathrm{H}\right\} 77.16\right.$; $\mathrm{CD}_{2} \mathrm{Cl}_{2}{ }^{1} \mathrm{H} 5.30,{ }^{13} \mathrm{C}\left\{{ }^{1} \mathrm{H}\right\} 53.84 ; d_{6}$-DMSO ${ }^{1} \mathrm{H} 2.50,{ }^{13} \mathrm{C}\left\{{ }^{1} \mathrm{H}\right\} 39.52$ ) or reported relative to $85 \% \mathrm{H}_{3} \mathrm{PO}_{4}$. EDESI-MS spectra were collected on a Micromass Q-Tof micro in

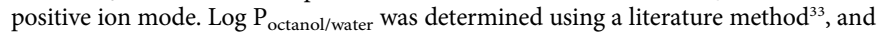
the correlation between $\log \mathrm{K}_{\mathrm{w}}$ and $\log \mathrm{P}$ was established using compounds with known $\log \mathrm{P}$ values (4-methoxyanilin 0.95 ,

4-bromanilin 2.26, naphtalene 3.30, tert-butylbnzene 4.11, pyrene 4.50 ).

Synthesis of $\mathrm{Ru}_{3}(\mathrm{CO})_{11}$ (3,5,6-bicyclophosphite-1,2-O-isopropylidene- $\alpha$-Dglucofuranoside) 1 . A solution of 3,5,6-bicyclophosphite-1,2-O-isopropylidene- $\alpha$ D-glucofuranoside ( $78 \mathrm{mg}, 0.031 \mathrm{mmol}$ ), in $\mathrm{CH}_{2} \mathrm{Cl}_{2} 5 \mathrm{~mL}$ was added to a solution of $\mathrm{Ru}_{3}(\mathrm{CO})_{12}(200 \mathrm{mg}, 0.31 \mathrm{mmol})$ under nitrogen at room temperature. The reaction mixture was stirred for $5 \mathrm{~min}$ and $\mathrm{Me}_{3} \mathrm{NO}(24 \mathrm{mg}, 0.031 \mathrm{mmol})$ was added. The reaction was stirred for $12 \mathrm{~h}$ and the solvent was removed and the compound isolated by flash chromatography (eluent $\mathrm{CH}_{2} \mathrm{Cl}_{2}: \mathrm{Et}_{2} \mathrm{O} 4: 1$ ). Yield $120 \mathrm{mg}$ (45\%), m.p. 125-127 ${ }^{\circ} \mathrm{C}$ decomp., elem. anal. calcd (\%) for $\mathrm{C}_{20} \mathrm{H}_{13} \mathrm{O}_{17} \mathrm{PRu}_{3}$ : C 27.95, $\mathrm{H}$ 1.52, $\mathrm{P}$ 3.60; found: $\mathrm{C} 27.67, \mathrm{H} 1.22$, P 3.99. ${ }^{1} \mathrm{H}$ NMR $\left(400.13 \mathrm{MHz}, \mathrm{CDCl}_{3}\right): \delta=6.10$ $(\mathrm{d}, J=3.8 \mathrm{~Hz}, 1 \mathrm{H} ; \mathrm{H}-1), 5.02(\mathrm{~m}, 1 \mathrm{H} ; \mathrm{H}-5), 4.63(\mathrm{~m}, 1 \mathrm{H} ; \mathrm{H}-3), 4.62(\mathrm{~d}, J=3.9 \mathrm{~Hz}, 1 \mathrm{H}$; $\mathrm{H}-2), 4.39(\operatorname{tr}, J=9.4,1 \mathrm{H} ; \mathrm{H}-6), 4.30\left(\mathrm{~m}, 1 \mathrm{H}, \mathrm{H}-6^{\prime}\right), 4.22(\mathrm{~m}, 1 \mathrm{H}, \mathrm{H}-4), 1.51(\mathrm{~s}, 3 \mathrm{H}$, $\left.\mathrm{CH}_{3}\right), 1.36\left(\mathrm{~s}, 3 \mathrm{H}, \mathrm{CH}_{3}\right) ;{ }^{31} \mathrm{P}\left\{{ }^{1} \mathrm{H}\right\}$ NMR $\left(161.98 \mathrm{MHz}, \mathrm{CDCl}_{3}\right): \delta=148.9 \mathrm{ppm}$. MS $\left(\mathrm{ESI}^{+}\right): \mathrm{m} / \mathrm{z}: 885[\mathrm{M}+\mathrm{Na}]^{+}$

Synthesis of $\mathrm{Ru}_{3}(\mathrm{CO})_{10}(3,5,6$-bicyclophosphite-1,2-O-isopropylidene- $\alpha$-Dglucofuranoside $)_{2} 2$. Compound 2 was prepared similar to that of 1 starting from 3,5,6-bicyclophosphite-1,2-O-isopropylidene- $\alpha$-D-glucofuranoside (155 mg, $0.062 \mathrm{mmol}), \mathrm{Ru}_{3}(\mathrm{CO})_{12}(200 \mathrm{mg}, 0.31 \mathrm{mmol})$ and $\mathrm{Me}_{3} \mathrm{NO}(70 \mathrm{mg}, 0.093$ mmol). Yield $178 \mathrm{mg}(53 \%)$, m.p. $150-151^{\circ} \mathrm{C}$ decomp., elem. anal. calcd (\%) for $\mathrm{C}_{28} \mathrm{H}_{16} \mathrm{O}_{22} \mathrm{P}_{2} \mathrm{Ru}_{3}$ : C 31.15, H 2.43, P 5.74; found: C 31.15, H 2.27, P 6.07. ${ }^{1} \mathrm{H}$ NMR $\left(400.13 \mathrm{MHz}, \mathrm{CDCl}_{3}\right): \delta=6.10(\mathrm{~d}, J=3.8 \mathrm{~Hz}, 1 \mathrm{H} ; \mathrm{H}-1), 4.98(\mathrm{~m}, 1 \mathrm{H} ; \mathrm{H}-5), 4.67-4.59$ (m, $2 \mathrm{H} ; \mathrm{H}-3, \mathrm{H}-2), 4.35$ (tr, $J=9.7,1 \mathrm{H} ; \mathrm{H}-6), 4.28\left(\mathrm{~m}, 1 \mathrm{H}, \mathrm{H}-6^{\prime}\right), 4.20(\mathrm{~m}, 1 \mathrm{H}, \mathrm{H}-4)$, $1.50\left(\mathrm{~s}, 3 \mathrm{H}, \mathrm{CH}_{3}\right), 1.34\left(\mathrm{~s}, 3 \mathrm{H}, \mathrm{CH}_{3}\right) ;{ }^{31} \mathrm{P}\left\{{ }^{1} \mathrm{H}\right\} \operatorname{NMR}\left(161.98 \mathrm{MHz}, \mathrm{CDCl}_{3}\right): \delta=149.7$, $148.4(3: 1) \mathrm{ppm}$. MS $\left(\mathrm{ESI}^{+}\right): \mathrm{m} / \mathrm{z}: 1105[\mathrm{M}+\mathrm{Na}]^{+}$.

Synthesis of $\mathrm{Ru}_{3}(\mathrm{CO})_{9}$ (3,5,6-bicyclophosphite-1,2-O-isopropylidene-

$\boldsymbol{\alpha}$-D-glucofuranoside) $)_{3} 3$. Compound 3 was prepared similar to that of 1 starting from 3,5,6-bicyclophosphite-1,2-O-isopropylidene- $\alpha$-D-glucofuranoside (232 mg, $0.094 \mathrm{mmol}), \mathrm{Ru}_{3}(\mathrm{CO})_{12}(200 \mathrm{mg}, 0.31 \mathrm{mmol})$ and $\mathrm{Me}_{3} \mathrm{NO}(95 \mathrm{mg}, 1.25 \mathrm{mmol}$ ). Yield $278 \mathrm{mg}(57 \%)$, m.p. $129-130^{\circ} \mathrm{C}$ decomp., elem. anal. calcd (\%) for $\mathrm{C}_{36} \mathrm{H}_{39} \mathrm{O}_{27} \mathrm{P}_{3} \mathrm{Ru}_{3}$ : C 33.27, H 3.02, P 7.15; found: C 33.23, H 2.80, P 7.33. ${ }^{1} \mathrm{H}$ NMR 

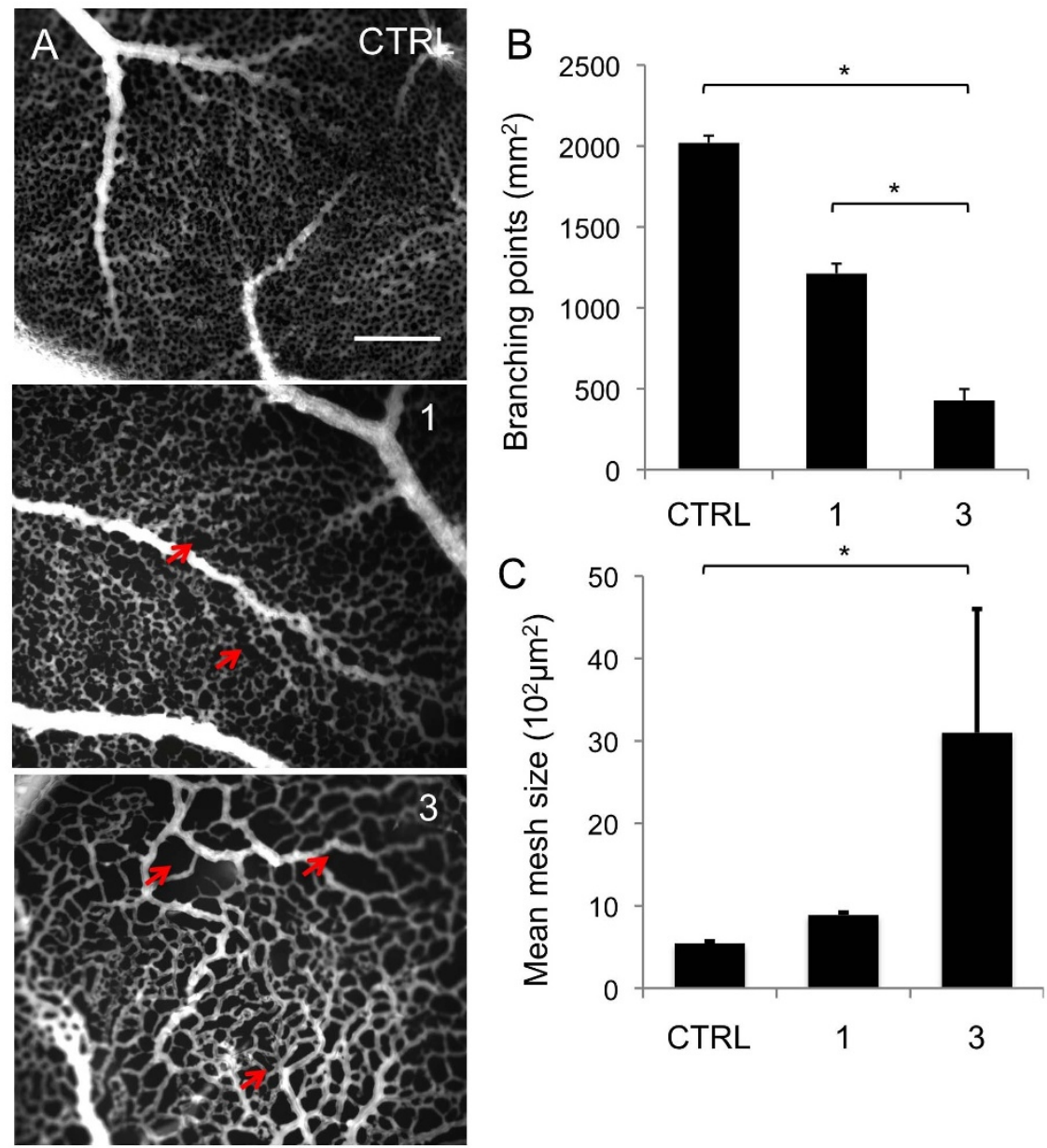

Figure $4 \mid$ Anti-angiogenic activity of 1 and 3. (A) Angiographic images of the developmental CAM (EDD 9) treated with $0.9 \% \mathrm{NaCl}$ (control) and 1 and $3(150 \mu \mathrm{M} /$ day $)$. The vasculature is visualized by FITC-dextran fluorescence angiography $\left(25 \mathrm{mg} / \mathrm{kg}, 20 \mathrm{kDa}, \lambda_{\mathrm{ex}}=470 \mathrm{~nm}, \lambda_{\mathrm{em}}=520 \mathrm{~nm}\right)$. Scale bar $200 \mu \mathrm{m}$. Red arrows indicate the avascular zones. Quantification of digital analysis of the fluorescence angiography images: number of branching points $\left(\mathrm{mm}^{2}\right)(\mathrm{B})$ and mean mesh size $\left(10^{2} \mu \mathrm{m}^{2}\right)(\mathrm{C})$ as markers of vessel density for CAM. $* \mathrm{P}<0.05$ was considered to be statistically significant. Error bars represent standard error of the mean.

$\left(400.13 \mathrm{MHz}, \mathrm{CDCl}_{3}\right): \delta=6.10(\mathrm{~d}, J=3.8 \mathrm{~Hz}, 1 \mathrm{H} ; \mathrm{H}-1), 4.96(\mathrm{~m}, 1 \mathrm{H} ; \mathrm{H}-5)$, 4.64- 4.57 (m, $2 \mathrm{H} ; \mathrm{H}-3, \mathrm{H}-2), 4.33$ (tr, $J=9.6,1 \mathrm{H} ; \mathrm{H}-6), 4.26$ (m, $\left.1 \mathrm{H}, \mathrm{H}-6^{\prime}\right)$, $4.18(\mathrm{~m}, 1 \mathrm{H}, \mathrm{H}-4), 1.50\left(\mathrm{~s}, 3 \mathrm{H}, \mathrm{CH}_{3}\right), 1.34\left(\mathrm{~s}, 3 \mathrm{H}, \mathrm{CH}_{3}\right) ;{ }^{31} \mathrm{P}\left\{{ }^{11} \mathrm{H}\right\} \mathrm{NMR}(161.98 \mathrm{MHz}$, $\left.\mathrm{CDCl}_{3}\right): \delta=150.3 \mathrm{ppm}$. MS $\left(\mathrm{ESI}^{+}\right): \mathrm{m} / \mathrm{z}: 1325[\mathrm{M}+\mathrm{Na}]^{+}$.

Synthesis of $\mathrm{Ru}_{3}(\mathrm{CO})_{8}(3,5,6$-bicyclophosphite-1,2-O-isopropylidene- $\alpha$-Dglucofuranoside $)_{4} 4$. Compound 4 was isolated as by-product in the synthesis of 2 and 3. M.p. $160-165^{\circ} \mathrm{C}$ decomp., elem. anal. calcd (\%) for $\mathrm{C}_{44} \mathrm{H}_{52} \mathrm{O}_{32} \mathrm{P}_{4} \mathrm{Ru}_{3}$ : C 34.77, H 3.45, P 8.15; found: C 34.45, H 3.29, P 8.10. ${ }^{31} \mathrm{P}\left\{{ }^{1} \mathrm{H}\right\} \mathrm{NMR}\left(161.98 \mathrm{MHz}, \mathrm{CDCl}_{3}\right): \delta$ $=153.1-148.3$ (multiplet) ppm.MS $\left(\mathrm{ESI}^{+}\right): \mathrm{m} / \mathrm{z}: 1325[\mathrm{M}+\mathrm{Na}]^{+}$.

Cell culture. Human A2780 and A2780cisR ovarian carcinoma cells were obtained from the European Centre of Cell Cultures (ECACC, UK), Human colon adenocarcinoma cells (HT29) were obtained from ATCC (France). Adenocarcinomic human alveolar basal epithelial cells (A549) and human breast adenocarcinoma cells (MDA-MB-231) were provided by the Institute of Pathology, CHUV, Lausanne, Switzerland. Human A2780 and A2780cisR ovarian carcinoma cells were routinely grown in RPMI 1640 medium supplemented with GlutaMAX (Gibco), heatinactivated fetal calf serum (FCS, Sigma, USA) (10\%) and antibiotics (Penicillin/ Streptomycin) at $37^{\circ} \mathrm{C}$ and $\mathrm{CO}_{2}(5 \%)$. $\mathrm{HT} 29$ and A549 cells were cultured in similar conditions except that RPMI 1640 was replaced by DMEM medium (Life Technologies, Carlsbad, USA). Immortalized human umbilical vein endothelial ECRF24 cells were provided by the Angiogenesis Laboratory (VUMC, The Netherlands) and were cultured in gelatin-coated flasks; RPMI 1640 culture medium containing 10\% heat-inactivated human serum (Sigma, USA), 10\% FCS, GlutaMAX and antibiotics, as described previously ${ }^{10}$.

Cell proliferation inhibition. Cytotoxicity was determined as described previously ${ }^{34}$ by the colorimetric MTT (3-(4,5-dimethyl-2-thiazolyl)-2,5-diphenyl-2H-tetrazolium bromide (Fluka) microculture assay on compounds freshly dissolved in DMSO
(Sigma-Aldrich, Buchs, Switzerland) at the required concentration and sequentially diluted in complete growth medium ( $\max 0.5 \%$ of DMSO), and incubated with cells for $72 \mathrm{~h}$.

Apoptosis assay. ECRF24 or A2780 cells were seeded on 6-well plates $\left(2 \times 10^{5}\right.$ cells/ well) and grown 24 hours in complete medium before treatment. Compounds 1-3 were freshly dissolved in DMSO, diluted in complete medium and added to the cells at the final concentrations indicated in Table 2. After incubation for $72 \mathrm{~h}$ apoptosis was measured by flow cytometric determination of subdiploid cells after DNA extraction and subsequent staining with propidium iodide (PI) as described previously ${ }^{10}$. Briefly, cells were harvested and subsequently fixed in $70 \%$ ethanol at $-20^{\circ} \mathrm{C}$. After $2 \mathrm{~h}$ the cells were re-suspended in DNA extraction buffer $\left(45 \mathrm{mM} \mathrm{Na}_{2} \mathrm{HPO}_{4}, 2.5 \mathrm{mM}\right.$ citric acid, and $1 \%$ Triton $\mathrm{X}-100, \mathrm{pH} 7.4$ ) for $20 \mathrm{~min}$ at $37^{\circ} \mathrm{C}$. PI was added to a final concentration of $20 \mu \mathrm{g} / \mathrm{mL}$ and log scale red fluorescence was analyzed on a FACSCalibur (BD Biosciences, NJ, U.S.).

Total ruthenium uptake. For evaluation of the cell uptake, cells were seeded in sixwell plates and grown to approximately $70 \%$ confluency and incubated with the clusters 1-3 at a concentration of $60 \mu \mathrm{M}$ for $5 \mathrm{~h}$. At the end of the incubation period, cells were rinsed twice with $2.0 \mathrm{~mL}$ of PBS, detached by adding $0.5 \mathrm{~mL}$ of enzyme free cell dissociation solution (Millipore, Switzerland), and collected by centrifugation. All samples were digested in ICP-MS-grade concentrated hydrochloric acid (Sigma Aldrich, Switzerland) for $3 \mathrm{~h}$ at room temperature and filled to a total volume of 8.0 $\mathrm{mL}$ with ultrapure water. Indium was added as an internal standard at a concentration of $0.5 \mathrm{ppb}$. Determinations of total metal contents were achieved on an Elan DRC II ICP-MS instrument (Perkin-Elmer, Switzerland) equipped with a Meinhard nebulizer and a cyclonic spray chamber. The ICP-MS instrument was tuned daily using a solution provided by the manufacturer containing $1 \mathrm{ppb}$ of each $\mathrm{Mg}$, In, Ce, $\mathrm{Ba}, \mathrm{Pb}$, and $\mathrm{U}$. External standards were prepared gravimetrically in an identical 
matrix to that of the samples (with regard to internal standard and hydrochloric acid) with single element standards (CPI International, The Netherlands).

Wound Assay (Migration). The migration capability of cells was measured using the wound assay ${ }^{10}$. Briefly, human breast adenocarcinoma (MDA-MB-231) cells and endothelial cells ECRF24 cultures were grown to confluence and cells were labeled with calcein AM (Molecular Probes, C3100MP, Carlsbad, USA) for 15 min (1:2000, Molecular Probes), and "scratch wounds" (with an approximate width of $350 \mu \mathrm{m}$ ) were made in the monolayer by removing cells with a sterile scratch tool (Peira Scientific Instruments, Belgium). Cultures were washed with PBS, and the medium was replaced by fresh medium and incubated with or without $\mathrm{Ru}$-carbonyl clusters. Plates were scanned using an Acumen eX3 laser scanner cytometer (TTP LabTech Ltd., UK) to acquire images for computational analysis of scratch sizes using UGR Scratch Assay 6.2 software (DCI Labs, Peira Scientific Instruments, Belgium).

Developmental CAM and Quantification of the Anti-angiogenic Response. Antiangiogenic efficacy of the Ru-carbonyl clusters was tested in the physiologically developing chicken embryo chorioallantoic membrane (CAM) model between embryo development days (EDDs) 6 and 9. Ru-carbonyl clusters were applied topically $(150 \mu \mathrm{M}, 3 \times 20 \mu \mathrm{l})$, at EDDs 6, 7 and 8 . The control eggs were treated with $(3 \times 20 \mu \mathrm{l} 0.9 \% \mathrm{NaCl})$. At EDD 9, the CAMs were visualized in ovo by means of FITC-dextran ( $20 \mathrm{kDa}, 20 \mu \mathrm{l}, 25 \mathrm{mg} / \mathrm{ml}$, Sigma-Aldrich) epi-fluorescence angiography and subsequently analyzed by the image-processing quantification method described previously ${ }^{35}$. Briefly, based on the FITC-dextran fluorescence angiography, the skeleton of the vascular network is built, and defined descriptors, i.e., branching points $\left(\mathrm{mm}^{2}\right)$ and the mean area of the vessel network meshes $\left(10^{2} \mu \mathrm{m}^{2}\right)$ give information on the vascular architecture. 5 to 6 eggs were tested per condition. Errors bars represent the standard error of the mean.

Statistical analysis. Values are given as the mean \pm SEM. Data are represented as averages of independent experiments, performed in duplicate or triplicate. Statistical analyses were done using the Student's t-test. ${ }^{*} \mathrm{P}<0.05$ was considered statistically significant.

1. Lippert, B. Cisplatin: Chemistry and Biochemistry of a Leading Anticancer Drug, Verlag Helvetica Chimica Acta, (1999).

2. Dhar, S. \& Lippard, S. J. Current Status and Mechanism of Action of PlatinumBased Anticancer Drugs. In Bioinorg. Med. Chem. 79-95 (Wiley-VCH Verlag) (2011).

3. Wu, B., Davey, G. E., Nazarov, A. A., Dyson, P. J. \& Davey, C. A. Specific DNA Structural Attributes Modulate Platinum Anticancer Drug Site Selection and Cross-Link Generation. Nucleic Acids Res. 39, 8200-8212 (2011).

4. Sava, G., Bergamo, A. \& Dyson, P. J. Metal-based antitumour drugs in the postgenomic era: what comes next? Dalton Trans. 40, 9069-9075 (2011).

5. Jakupec, M. A., Galanski, M., Arion, V. B., Hartinger, C. G. \& Keppler, B. K. Antitumor metal compounds: more than theme and variations. Dalton Trans., 183-194 (2008).

6. Hartinger, C. G., Metzler-Nolte, N. \& Dyson, P. J. Challenges and Opportunities in the Development of Organometallic Anticancer Drugs. Organometallics 31, 5677-5685 (2012).

7. Hartinger, C. G., Jakupec, M. A., Zorbas-Seifried, S., Groessl, M., Egger, A. \& Bergar, W. KP1019, A New Redox-Active Anticancer Agent - Preclinical Development and Results of a Clinical Phase I Study in Tumor Patients. Chem. Biodiversity, 5, 2140-2155 (2008).

8. Sava, G., Gagliardi, R., Bergamo, A., Alessio, E. \& Mestroni, G. Treatment of metastases of solid mouse tumours by NAMI-A: comparison with cisplatin, cyclophosphamide and dacarbazine. Anticancer Res. 19, 969-972 (1999).

9. Chatterjee, S., Kundu, S., Bhattacharyya, A., Hartinger, C. \& Dyson, P. The ruthenium(II)-arene compound RAPTA-C induces apoptosis in EAC cells through mitochondrial and p53-JNK pathways. J. Biol. Inorg. Chem. 13, 1149-1155 (2008)

10. Nowak-Sliwinska, P., van Beijnum, J. R., Casini, A., Nazarov, A., Wagnières, G. \& van den Bergh, H. et al. Organometallic Ruthenium(II) Arene Compounds with Antiangiogenic Activity. J. Med. Chem. 54, 3895-3902 (2011).

11. Nowak-Sliwinska, P., Weiss, A., van Beijnum, J. R., Wong, T., Lovisa, B., Ballini, J. P. et al. Angiostatic kinase inhibitors to sustain photodynamic angio-occlusion. J. Cell. Mol. Med. 16, 1553-1562 (2012).

12. Astashkina, A., Mann, B. \& Grainger, D. W. A critical evaluation of in vitro cell culture models for high-throughput drug screening and toxicity. Pharmacol. Ther. 134, 82-106 (2012)

13. Kong, K. V., Leong, W. K., Ng, S. P., Nguyen, T. H. \& Lim, L. H. Osmium carbonyl clusters: a new class of apoptosis inducing agents. Chem. Med. Chem. 3 , 1269-1275 (2008).

14. Allardyce, C. S. \& Dyson, P. J. The interactions of low oxidation state transition metal clusters with DNA: potential applications in cancer therapy. J. Cluster Sci. 12, 563-569 (2001).

15. Foresti, R., Bani-Hani, M. \& Motterlini, R. Use of carbon monoxide as a therapeutic agent: promises and challenges. Intensive Care Med. 34, 649-658 (2008).
16. Alberto, R. \& Motterlini, R. Chemistry and biological activities of CO-releasing molecules (CORMs) and transition metal complexes. Dalton Trans., 1651-1660 (2007).

17. Motterlini, R. et al. Carbon monoxide-releasing molecules: characterization of biochemical and vascular activities. Circ. Res. 90, E17-24 (2002).

18. Schatzschneider, U. Photoactivated Biological Activity of Transition-Metal Complexes. Eur. J. Inorg. Chem. 2010, 1451-1467 (2010).

19. Nazarov, A. A. \& Dyson, P. J. Metal phosphorus complexes as antitumor agents. In Phosphorus Chemistry: Catalysis and Material Science Applications, Vol. 37 (eds. Gonsalvi, L. \& Peruzzini, M.) 445-461 (Springer 2011).

20. Hartinger, C. G., Phillips, A. D. \& Nazarov, A. A. Polynuclear Ruthenium, Osmium and Gold Complexes. The Quest for Innovative Anticancer Chemotherapeutics. Curr. Top. Med. Chem. 11, 2688-2702 (2011).

21. Blazina, D. et al. NMR Studies of $\mathrm{Ru}_{3}(\mathrm{CO})_{10}\left(\mathrm{PMe}_{2} \mathrm{Ph}\right)_{2}$ and $\mathrm{Ru}_{3}(\mathrm{CO})_{10}\left(\mathrm{PPh}_{3}\right)_{2}$ and Their $\mathrm{H}_{2}$ Addition Products: Detection of New Isomers with Complex Dynamic Behavior. J. Am. Chem. Soc. 123, 9760-9768 (2001).

22. Deeming, A. J., Donovan-Mtunzi, S., Kabir, S. E. \& Manning, P. J. New isomers of $\left[\mathrm{Os}_{3}(\mathrm{CO})_{10}\left(\mathrm{PMe}_{2} \mathrm{Ph}\right)_{2}\right]$ and $\left[\mathrm{Os}_{3}(\mathrm{CO})_{9}\left(\mathrm{PMe}_{2} \mathrm{Ph}\right)_{3}\right]$. Dalton Trans. 1037-1041 (1985).

23. Crawford, E., Dyson, P., Forest, O., Kwok, S. \& McIndoe, J. S. Energy-dependent Electrospray Ionisation Mass Spectrometry of Carbonyl Clusters. J. Cluster Sci. 17, 47-63 (2006).

24. Berger, I., Hanif, M., Nazarov, A. A., Hartinger, C. G., John, R. O. \& Kuznetsov, M. L. et al. In Vitro Anticancer Activity and Biologically Relevant Metabolization of Organometallic Ruthenium Complexes with Carbohydrate-Based Ligands. Chemistry Europ. Journal 14, 9046-9057 (2008).

25. Nazarov, A. A. et al. Anthracene-Tethered Ruthenium(II) Arene Complexes as Tools To Visualize the Cellular Localization of Putative Organometallic Anticancer Compounds. Inorg. Chem. 51, 3633-3639 (2012).

26. Hartinger, C. G., Nazarov, A. A., Ashraf, S. M., Dyson, P. J. \& Keppler, B. K. Carbohydrate-Metal Complexes and their Potential as Anticancer Agents. Curr. Med. Chem. 15, 2574-2591 (2008).

27. Hanif, M., Nazarov, A. A., Hartinger, C. G., Kandioller, W., Jakupec, M. A., Arion, V. B., Dyson, P. J. \& Keppler, B. K. Osmium(ii)-versus ruthenium(ii)-arene carbohydrate-based anticancer compounds: similarities and differences. Dalton Trans. 39, 7345-7352 (2010).

28. Hanif, M., Nazarov, A. A., Legin, A., Groessl, M., Arion, V. B., Jakupec, M. A., Tsybin, J. O., Dyson, P. J., Keppler, B. K. \& Hartinger, H. G. Maleimidefunctionalised Organoruthenium Anticancer Agents for Tumour Targeting. Chem. Commun. 48, 1475-1477 (2012).

29. Dyson, P. J., Hearley, A. K., Johnson, B. F. G., McIndoe, J. S. \& Langridge-Smith, P. R. R. UV laser desorption/ionisation mass spectrometry of the triruthenium clusters $\mathrm{Ru}_{3}(\mathrm{CO})_{12}-\mathrm{n}\left(\mathrm{PPh}_{3}\right)_{\mathrm{n}}(\mathrm{n}=1,2$ and 3). Inorg. Chem. Commun. 2, 591-594 (1999).

30. Woo, H. Y. \& Heo, J. Sorafenib in liver cancer. Expert Opin. Pharmacother. 13, 1059-1067 (2012).

31. Heng, D. Y. \& Kollmannsberger, C. Sunitinib. Rec. Res. Cancer Res. 184, 71-82 (2010).

32. Hartmann, J. T., Haap, M., Kopp, H. G. \& Lipp, H. P. Tyrosine kinase inhibitors - a review on pharmacology, metabolism and side effects. Curr. Drug Metab. 10, 470-481 (2009).

33. Minick, D. J., Frenz, J. H., Patrick, M. A. \& Brent, D. A. A comprehensive method for determining hydrophobicity constants by reversed-phase high-performance liquid chromatography. J. Med. Chem. 31, 1923-1933 (1988).

34. Nazarov, A. A., Risse, J., Ang, W. H., Schmitt, F., Zava, O. \& Ruggi, A. Anthracenetethered ruthenium(II) arene complexes as tools to visualize the cellular localization of putative organometallic anticancer compounds. Inorg. Chem. 51, 3633-3639 (2012)

35. Nowak-Sliwinska, P., Ballini, J. P., Wagnieres, G. \& van den Bergh, H. Processing of fluorescence angiograms for the quantification of vascular effects induced by anti-angiogenic agents in the CAM model. Microvasc. Res. 79, 21-28 (2010).

\section{Acknowledgements}

The authors are grateful for financial support from the Swiss National Science Foundation, National Centre of Competence in Research "Chemical Biology - Visualisation and Control of Biological Processes Using Chemistry" (to PJD) and Dr. J. Jacobi Trust (to PNS). The authors thank Tse Wong for technical assistance, Maxime Dubois for the help in the synthesis of the compounds and Dr. Lucienne Juillerat-Jeanneret (Institute of Pathology, CHUV, Lausanne, Switzerland) for providing the MDA-MB-231 cells.

\section{Authors contribution}

A.A.N., P.N.S., A.W.G., H.v.d.B. \& P.J.D. conceived the project. The authors conducted the following experiments: A.A.N. (synthesis of the compounds), P.N.S. (in vitro and in vivo experiments), M.B. (in vitro and in vivo experiments), O.Z. (in vitro experiments), J.R.v.B. (in vitro experiments), D.M.C., Z.A. and J.S.M. (mass spectrometry), M.G. (Ru uptake). A.A.N., P.N.S., O.Z., J.R.v.B., A.W.G., J.S.M. \& P.J.D. contributed in data anylysis and A.A.N., P.N.S., O.Z., A.W.G., J.S.M. \& P.J.D. wrote the manuscript. 


\section{Additional information}

Competing financial interests: The authors declare no competing financial interests. License: This work is licensed under a Creative Commons

Attribution-NonCommercial-NoDerivs 3.0 Unported License. To view a copy of this license, visit http://creativecommons.org/licenses/by-nc-nd/3.0/
How to cite this article: Nazarov, A.A. et al. Synthesis and characterization of a new class of anti-angiogenic agents based on ruthenium clusters. Sci. Rep. 3, 1485; DOI:10.1038/ srep01485 (2013). 